\title{
Niall O'Loughlin
}

Loughborough University

Univerza v Loughboroughu

\section{The Music of Uroš Krek: Towards a Definition of its Style}

\section{Glasba Uroša Kreka: k vprašanju opredelitve njegovega stila}

Prejeto: 26. avgusta 2008

Sprejeto: 5. septembra 2008

Ključne besede: Uroš Krek, neoklasicizem, ljudska glasba, melodične celice

IZVLEČEK

Avtor opredeli stil Uroša Kreka, katerega glasba slovi po svoji visoki kakovosti in čustveni vsebini. Pri tem so upoštevana osnovna stilna obdobja, neoklasicizem, vpliv ljudske glasbe, melodične celice ter kombinacije vseh treh, pri čemer ugotavlja, da med le-temi ne obstaja jasno začrtana meja.
Received: 26th August 2008

Accepted: 5th September 2008

Keywords: Uroš Krek, neo-classicism, folk music, melodic cells

ABSTRACT

The author defines the style of the composer Uroš Krek whose music has a reputation for high quality and emotional content. He uses the basic stylistic periods, neo-classicism, folk music influence, melodic cells, and a combination of these three, but argues that there is no clear-cut division between them.

The music of Uroš Krek (1922-2008) has for a long time been widely recognised for its high quality, as it clearly communicates its message at all levels with its audience without in any way compromising its impeccable standards. The composer studiously avoided following any fashion, as he felt that music comes from the heart and is not produced simply to fit in with any stereotyped formula. The development of his music has always been evolutionary, with new works growing organically out of the previous ones, because the composer viewed any sudden change of style as something to be avoided, and considered that it could be thought to be a false identity imposed on his musical thinking. Despite all these pointers, however, the essential character of Krek's music remains curiously elusive. What, in fact, is the essential secret of his art? 
A superficial acquaintance with Krek's music suggests that it falls roughly into four periods: the early neo-classical phase when he was establishing a style (1946-58); the following years in which his idiom was influenced by folk music, especially that of Slovenia (1958-1969); a period in which melodic cells became an important part of his technique (1970-1980); the final period in which his music drew features from all these periods (1980 onwards). A greater familiarity with the individual works makes clear that these useful simplifications can be misleading, because within them they include a wonderful variety and mixture of techniques, and that there are no rigid stylistic divisions in his musical output. Over his creative working life, Krek developed his music by evolution with a tightly organised style that communicates directly and effectively. His music has never become 'advanced' stylistically, although it does sometimes use new techniques. It is always conceived sonically, with excellent use of instrumental and/or vocal resources, especially but not exclusively string instruments, together with strong and distinctive melodic writing and vivid harmonic sounds. ${ }^{1}$ The formal planning of Krek's music is varied and progressively more flexible. A strong characteristic of this wide-ranging development is the way that the different features seem to arise naturally in the course of the composition of each work, and then take their place in the range of techniques at his disposal.

Krek studied in Ljubljana under Škerjanc and Švara, completing his studies in 1947. In the previous year he had composed an imaginatively written Sonata for violin and piano that shows the romantic influence of Škerjanc. During the next few years he developed a neo-classical idiom, in pieces such as the Simfonietta of 1951, ${ }^{2}$ Mouvements concertants for strings of 1955 and the Sonatina for strings of 1956. It is these works that form the bedrock of his style.

Let us consider one of the composer's most substantial and accomplished early works. The Simfonietta is traditional in outlook, concisely written and attractive in sound. While some commentators have suggested a strong influence of Prokofiev, this is relatively slight because his music lacks the Russian's biting turns of phrase and presents a distinctive lightness of touch and a humanity that is apparent in the gently turned melodic phrases and springing rhythms that characterise the music of this period. Moreover, the second theme of the first movement has more than a hint of the march from the third movement of Tchaikovsky's Symphony No.6 in B minor (Pathétique). The work is strongly thematic, with the subtly shaped melodic material of the first movement treated in a symphonic development that concentrates on the augmentation of the first theme and inversions of the others. It is notable that traditional key-relationships are maintained in both exposition and recapitulation. In the second movement Krek excels himself in his ingenuity, economy and emotion. The opening theme (Andantino) is developed in three extended free variations, more in the nature of transformations. Krek combined scherzo (first variation, Poco presto) and slow movement (second variation, Adagio molto cantabile), each 'variation' being strongly

\footnotetext{
A particularly valuable study of the sonorities of Krek's music is found in Andrej Rijavec: 'Klangliche Realisierungen im Werk von Uroš Krek - Zvočne realizacije v delu Uroša Kreka', Muzikološki zbornik xii (1976), pp. 97-109.

Krek used this spelling in the published score (Edicije DSS 460, 1973) and the Musica Slovenica recording (FLP 10-015) rather than the strictly correct Latin form 'Sinfonietta'.
} 
contrasted, while the third alternates slow and fast tempos before a brief return to the opening Andantino. This rather prosaic description conceals the fact that this movement contains the emotional heart of the work with short phrases that are intense in feeling and hauntingly memorable. It is in the slow parts of the third variation that the radiant intensity of his string writing emerges so powerfully, with a yearning phrase that is closely harmonised diatonically; this section appears three times, more emotionally involving each time. Krek's ability to create such passages occurs again and again in his later works, but surprisingly they almost defy analysis such is the integration of the melody, the harmony and the sound quality. The finale again asserts its thematic nature with a simple theme harmonised on a tonic chord, an almost banal touch countered by an immediate symphonic development with elements from the theme reversed and reorganised. A central episode rather than a development proper follows, with a free recapitulation of the main material. All this may suggest a straightforward neo-classical composer, but in every respect the work is subtly and imaginatively composed with some unpredictable moves. The sound quality is completely distinctive and the form, while touching aspects of tradition, is moving towards a convincing but totally unstereotyped organisation.

From 1958 to 1967 Krek worked at the Ljubljana Ethnological Institute, making close contact with folk music, particularly of Slovenia and the neighbouring republic of Croatia. Krek's views on folk music are very revealing. Unlike his Croatian contemporary, Milko Kelemen, who wrote an article in which he said 'farewell to folklore' as something of a relief, ${ }^{3}$ Krek positively welcomed its influence on his music. In an article entitled 'Encounter with Folklore', ${ }^{4}$ he made clear his belief that music that derived from folklore enriched his art in a way that many of the then current trends in Central Europe did not. Krek was very careful not to mention names, but it is clear that he was thinking of the composers who had gathered around his German contemporary, Karlheinz Stockhausen.

When one considers the music of this period, it is clear that Krek's musical style was by this time too fully formed for this to produce any fundamental change, but there are numerous instances in his music of this period in which melodic and rhythmic elements of folk music appear. Therefore it is more appropriate to consider Krek's music of this time as an extension of his neo-classical idiom. A good work to consider in this context is the short orchestral piece Rapsodični ples, a reworking in 1959 by the composer of an earlier commission for violin and piano. It draws on a variety of folk materials from all over the former Yugoslavia, yet it is true to the style that Krek had established in his earlier music. The Concerto for horn and strings of 1960 does have some folk-like influences: the first movement contrasts a simple unaccompanied horn melody with a predominantly rhythmic section that uses $8 / 8$ time divided into 3+2+3, a common folk rhythm from Slovenia and from the Medjimurje region of Croatia. The combined rhythm used in this movement offers a good rhythmic

\footnotetext{
Milko Kelemen: 'Abschied von der Folklore', Melos xxvi (1959), pp. 178-80.

Uroš Krek: 'Susret sa folklorom', Zvuk 75-76 (1967), pp. 15-17; and in Slovene, 'Srečanje s folkloro', Naši zbori XVIII, no. 5 (1966), as reprinted in Slovenski skladatelji akademiki - Slovenian Composers Academicians (Ljubljana: Slovenska akademija znanosti in umetnosti, 2003), pp. 122-29, together with an English translation.
} 
contrast to the $4 / 4$ time of most of the movement. In addition, though, we encounter new stylistic features, especially the development and extension of the chromatically inflected lines found in the earlier neo-classical pieces, as well as the more 'open' intervals of fourths and fifths. Krek's melodic lines are shaped with an ear for balance but not undue symmetry, the near-repetitions carefully crafted to allow the listener to absorb the ideas without haste. But other features are also carried over from his earlier works: his harmonies, sometimes static with use of ostinato patterns based on triadic formations, and frequent chord sequences rich with added notes, with or without melodic decoration.

This grafting of folk music features continues in two more works for solo instruments and orchestra: Inventiones ferales for violin and strings of 1962 and the Concertino for piccolo and orchestra of 1967. The earlier work sounds anything but folk-like, but Krek was able to work his folk connections into his varied style without difficulty. The rhapsodic writing and fast-moving folk-like virtuoso passages of the central section of the first movement give a taste of fondness for the techniques and there is also some use of the Istrian mode. There is a melodic passage that turns back on itself with chromatically altered notes, one very good method of Krek's for enhancing the emotional effect of the music (Ex. 1). It is a feature that is found in much of Krek's subsequent melodic writing, especially from the mid 1970s. But alongside this there is a new mood: intended as a memorial to the composer's father, the work has two brooding slow movements flanking a central Risoluto of typical Krekian rhythmic vigour. The first begins with a highly chromatic fugato introduction using a non-serial 'twelve-note' theme. The harmonic language is notable for its simple use of chord sequences. One example can be heard in a passage in which a simple progression (dominant-tonic in $\mathrm{C}$ major) is smothered by added notes and then the sudden removal of all the additions reveals a plain $\mathrm{C}$ major chord.

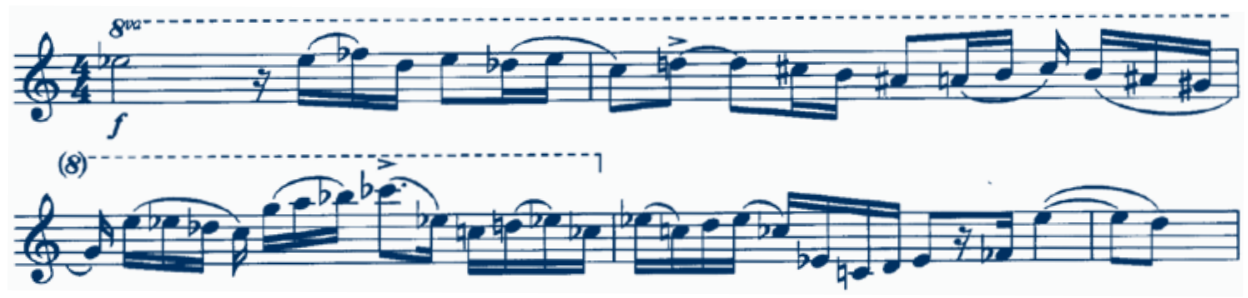

Example1. Inventiones ferales - second movement.

The two-movement Concertino for piccolo and orchestra is equally distinctive, a much lighter work, and smaller in scale. As in the earlier works, there are passages using folkderived rhythms, e.g. $2+3+3$ in the coda of the second movement. But as in other works of this period there are numerous other features, including an increasing use of free rhythm in unbarred sections. The melodic materials make memorable motifs that help to unify the work, very much a strong feature of the music. But there are looks back to the past as well: a curious little phrase at the end of the first movement has more than a 
passing resemblance to a theme from Prokofiev's Lieutenant Kijé. There is no suggestion here that the composer made an unacknowledged borrowing, more a coincidence. This type of melodic phrase is a good example of Krek's use of a melody that turns back on itself with chromatically altered notes, a feature mentioned above in Inventiones ferales. The formal plans of the two movements owe something to traditional schemes, but Krek is approaching the stage at which it is less important to mention similarities with these forms. Motivic connections constituting the main thematic interest present an effective unifying factor. In addition to this, Krek added a wealth of decorative and contrapuntal detail, as he did in the central movement of the earlier Inventiones ferales.

From the same year, 1967, comes a cycle of six songs for high voice and string orchestra, which includes two harps, called Staroegiptovske strofe ('Old Egyptian Stanzas'). Comparable in some ways to Benjamin Britten's Les Illuminations of 1939, Krek's vocal lines show his customary variety, ranging from those with simple, folk-like and mostly stepwise movement to recitative and more elaborate word-setting, in which the words do not appear to dictate the course of the melodic line, yet they fit its inflections very well. There are numerous passages in which the string parts seem to follow a separate development from that of the vocal line. Harmonically, Krek always aimed to a use a straightforward tonal harmonic progression, even if he enriched the chords with added notes.

All these pieces show in one way or another some aspect of the influence of folk music, but these features are all fully integrated into the now established style that Krek had developed. Right in the middle of these achievements, chronologically, he did make one adventure into arranging folk music directly, in Pet narodnih pesmi ('Five Folk Songs') of 1963, which employ melodies from the Medjimurje region of Croatia as well as from Rezija and Prekmurje in Slovenia itself. Its characteristics include a frequent use of pentatonic melodies and use of combination rhythms, e.g. $4+6 / 8$ and $3+2+2 / 8$. In these settings Krek has harmonised the melodies pianistically in a harmonic idiom that is similar to the extended diatonicism of his other works from the early 1960s. In every way the melodic line of the singer is always presented clearly, with a correspondingly effective projection of the words.

After this period in which folk music took its place in his style, Krek expanded and developed his use of the short motif. It was not an abrupt change, but more a shift of emphasis, with the folk influence never being far away. It led to a succession of works which employ a concise economy of means, in some cases almost obsessively so, that leave one amazed at their sheer sense of intellectual focus. This is not to say that Krek's emotional and dramatic sense is lost - far from it - but it took its natural place in his musical idiom.

It is instructive to take a brief work, Thème varié, for trombone and piano, to illustrate Krek's newer manner of varying his thematic material. This is shown in the composer's reprises, which earlier had been fairly literal, but more recently had become only suggestive. The theme is subjected to considerable but recognisable transformations throughout the work..$^{5}$ One new feature in this work is the use of an arch plan, suggesting some 
influence from certain works of Bartók, notably the String Quartet No.5 and the Music for strings, percussion and celesta. This would seem to be confirmed by a study of the later Solo-Sonata for two violins.

The next few pieces by Krek were three finely crafted chamber works, of which the first two, Episodi concertanti for wind quintet and the Sonatina for solo oboe, are essentially small-scale and lightweight in character. The third chamber work of this group, the Solo-Sonata for two violins of 1971, is a far more substantial threemovement work of some 22 minutes' duration with a complex formal structure. Even with an abundance of thematic material, the composer's customary thematic connections give the work a strong formal coherence. The opening theme of the first movement is subjected to transformations similar to those found in Thème varié, in rhythm and intervals. In the central 'Tempo primo' the rhythms of the opening are suggested, although the melodic lines themselves are drastically altered. Krek had now virtually abandoned classical forms, preferring to use the arch-forms favoured by Bartók. A good example of this is the second movement, whose form can be defined by tempo as ABCBA, although the thematic material of the two B sections is different. The middle sections frequently employ the intervals and figurations that appeared in the first movement. The plan of the finale is also straightforward, ABCDBA, with a fairly literal reprise of $\mathrm{A}$ and $\mathrm{B}$ in reverse order. The parallel with Bartók can also be heard in numerous canons, imitations and mirror forms, but also very strikingly in passages in the finale, with its irregular rhythms and melodic lines of limited range.

Up to now in this discussion of Krek's music, his use of traditional forms has been frequently mentioned, but usually, as mentioned above, the detailed plans have shown no slavish adherence to traditional schemes. In his Sinfonia per archi Krek breaks completely with tradition in his formal working and in other aspects of his style, too; in all respects it represents a major landmark in his development and, despite its short duration (15 minutes), it is masterly in its unorthodox control of musical materials. These include the use of freely coordinated parts, especially ostinatos, a greater use of angular and fragmented melodic lines, and a concentration on short sections of intense motivic working. Juxtapositions of material, motifs, harmonies and textures are often abrupt. The three movements have unexceptional tempos; the first is slowish, the second slow and the third quite fast, but Krek untypically relied completely on metronome markings to define these tempos. The titles of the movements, Pozivanje ('Invocation'), Prebujenje ('Awakening') and Ozdiv ('Return'), would seem to have nothing more than general rather than programmatic significance.

It is in Krek's thematic and motivic working in the Sinfonia per archi that his brilliance and imagination are shown. Even when the economy of material is evident, the logic and variety of treatment keep the musical interest to the fore. One example that must suffice to illustrate this involves the use of the octave leap, which often begins phrases, and which sometimes is altered by a semitone and at others it has an intervening note, e.g. a fourth. In the second movement it is the diminished octave that first appeared in the first movement which features prominently, both 
rising and falling, with or without the intermediate note, usually the third. The minor ninth occurs much less often, while extensive use of similar leaps of the octave, minor ninth and major seventh appears in the finale. Krek maintains no rigid sense of traditional tonality because of his avoidance of progressions that might define a key-centre, although triadic shapes are common in the harmonies. The focal point of the work is the note E, with which the work starts so memorably with a fugato on one note.

The motivic compression of the Sinfonia per archi was followed in the succeeding works in almost virtuoso fashion by four chamber works from 1975-77 which add immeasurably to Krek's achievement. The Duo for violin and cello, the solo piano piece Sur une mélodie, the Sonata for clarinet and piano, and the Trio for violin, viola and cello. Sur une mélodie and the Clarinet Sonata are both in two parts, slow and quick, the former playing without a break and the latter in two separate movements. The first part of the former features typically Krekian harmonies, but often breaks into two-part textures in which the melody of the title played in one hand is decorated by a range of elaborate flourishes in the other.

The first movement of the Sonata goes much further with an elaborate interconnection between the players' parts in a way that totally respects the two instruments' particular abilities. Krek integrates the two parts with many short motifs that often dominate the texture. Particularly prominent is a four-note grouping or cell which appears both melodically and harmonically, but whose exact intervals are constantly changing. This four-note cell is the source of much of the music of the second movement of the Sonata for clarinet and piano, entitled Toccata con canzone, a tourde-force of motivic working, and a staggering display of how these fragments can be repeated, juggled, transformed and juxtaposed. The four-note motif in its basic form rises or falls an octave with an intervening third or sixth and then returns to the middle note normally lowered by a semitone, a characteristic feature of Krek's style. Ex. 2 presents the opening of the second movement in which these shapes can be traced in their various forms, a passage which repays very close study for its numerous repetitions, imaginative variety and subtle transformations. The intellectual side of the Sonata is balanced by a warm and moving intensity in the first movement and in the second movement by an exultant virtuosity that always arises from the needs of the music. One notes that the second part of Sur une mélodie also uses the same four-note cell as the Clarinet Sonata, but in a much less insistent and explicit fashion. 

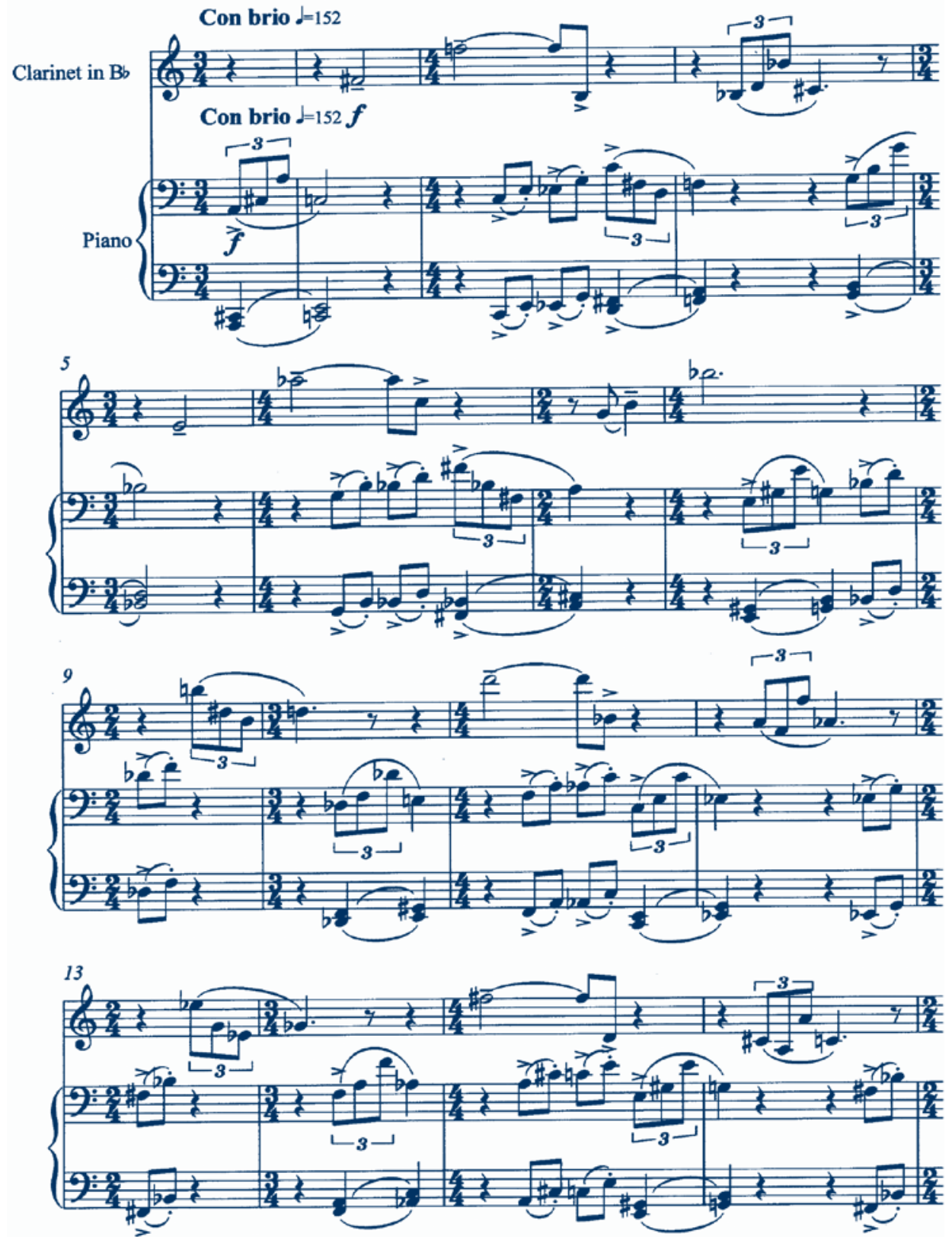
N. O'LOUGHLIN • THE MUSIC OF UROŠ KREK:
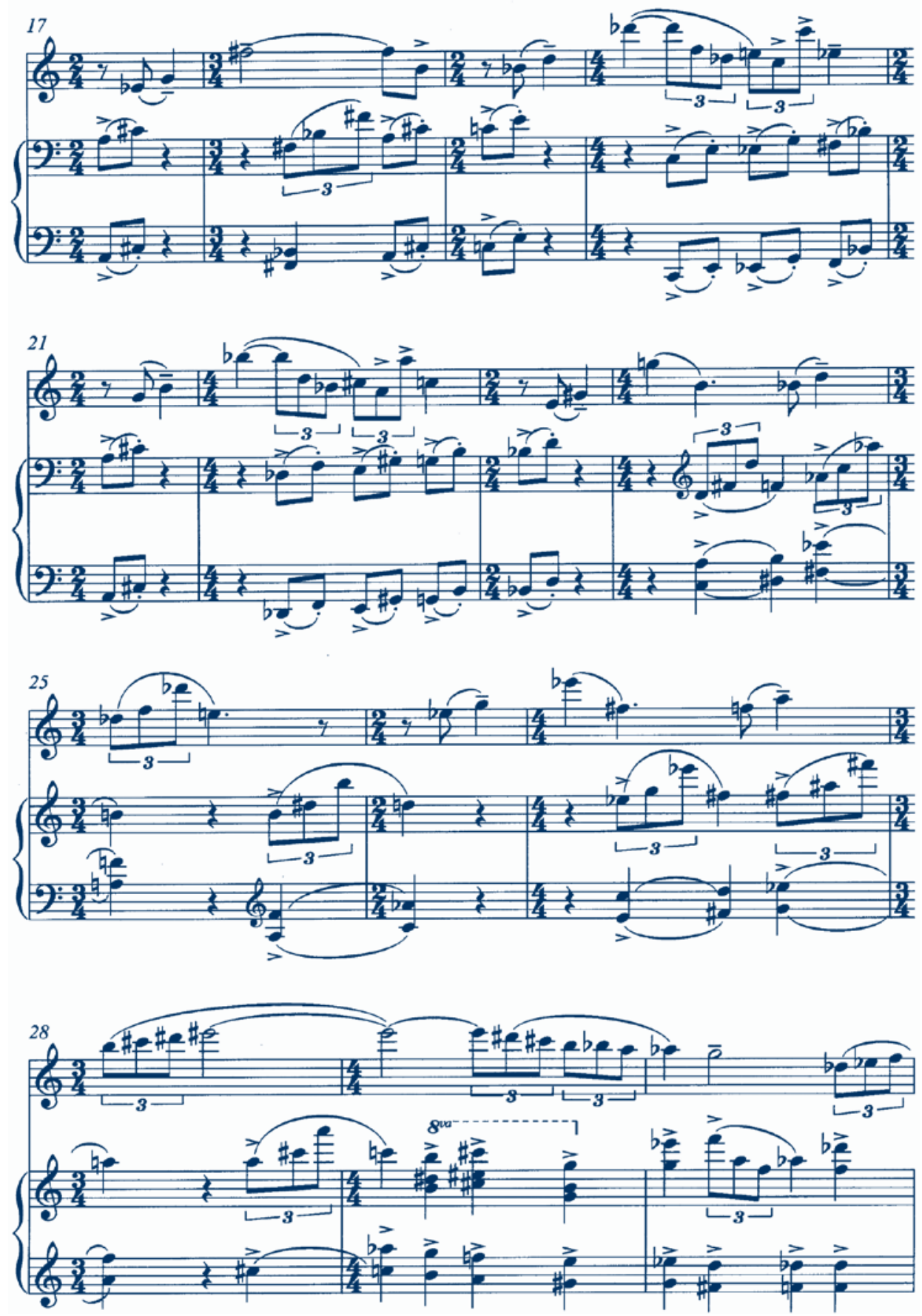

Example 2. Sonata for clarinet and piano - opening of second movement. 
The modestly titled Duo for violin and cello of 1975 is a substantial work of nearly 20 minutes' duration. With its three movements, laid out in unorthodox fashion as slow, quick, quick, there are many subtle tempo changes and an incredible network of motivic identities and transformations. The relationship between the parts of the two players is very varied and constantly changing. Free contrapuntal lines merge into imitative passages and frequently they are both interrupted magically with moments of harmonic stasis using the type of glowing harmonies that Krek had exploited so vividly in the Sinfonia per archi. The last work of this group, the Trio, has much in common with the Duo of 1975. The composer's skill in handling string writing and keeping the textures crystal clear is apparent at every stage in the work.

After this intensely intellectual group of works, Krek's style appeared to mellow. He drew back into his music all the other elements that had played such an important part in his earlier music without losing the lessons learned from the previous decade. The relaxation in concentration was only an illusion, of course, as the finest works from this period stand high in Slovene music of the second half of the 20th century, with techniques established in his earlier music, applied imaginatively and almost unobtrusively. The small-scale choral works, for example, use a well-managed combination of homophonic and contrapuntal techniques. Three Autumn Songs from 1991 for mixed chorus combine straightforward but subtly varied imitation between the different voices, with chordal passages of an unambiguous luminosity that one finds at all stages in the composer's career and false relations creating a very colourful sound. Word setting in Salmo XLII also of 1991 and in the four-part chorus, Vester, Camenae of 1994 makes the texts clearly audible, with numerous examples of words being sensitively presented. While the composer keeps his music within a broad tonality, his use of a wide range of dissonance points the meaning of the words very emphatically. The choral setting of Jutranja pesem ('Morning Song') by Adam Bohorič with accompaniment of brass quintet and bells is a typically unusual touch by Krek who builds up a range of motifs that infiltrate the texture without ever dominating the choral parts. Krek's thanksgiving cantata for soprano, trumpet and organ called Cantus gratias agentis - Zahvalni spev of 1994, set to Krek's own Latin words, appears like a baroque passacaglia or a series of free variations. Its various melodic cells or motifs are expanded, contracted or transformed in the composer's flexible manner and it is the contrast of intense emotion with his economy of means which gives the work its power. Even more impressive is the cantata Canticum Resianum of 1988 for mezzo-soprano and chamber orchestra (mostly strings). Here Krek returns to his use of original folk music, including two popular songs from Rožice in Rezija, in a work which is variously radiant, luminous and dance-like. It is a reminder of how much Krek's melodic lines owe, sometimes distantly, to folk music.

In Krek's recent works for solo instrument and piano his handling of form shows little debt to any models, but is always controlled by a skilful handling of motifs and harmonic material. Typical of this is his Appassionato for flute and piano of 1989, a single-movement work in a number of sections of varying tempos which are almost seamlessly linked by the similarity of motifs. Krek balances repetition and change with the development of new phrases out of previous ones, although there is also a connection with traditional formal structures. Even a modest single-movement work like the 
charming Sarabanda per Nataša of 1993 for clarinet and piano is scrupulously worked out in all its motivic transformations. As in Appassionato for flute, the shorter sections are naturally grouped by their sharing of melodic motifs and by the skilfully composed transitions between them. It happily combines the style of Krek's neo-classical music of the 1950s with a neat and precise economy of melodic motifs.

While Krek's writing for wind instruments is sonically effective and gratefully written, but often difficult to play, his music for string instruments is exceptional. Vigoroso of 1991 and Seconda sonata (Erinnerungen) of 1994 for violin and piano display numerous of Krek's techniques. The former is a single-movement multi-tempo piece that has a fantasy character with some features which suggest folk violin playing, with a strong emotional character coupled with thematic unity. Seconda sonata (Erinnerungen) is more expansive and cast in three separate movements, with considerable variety within each one. In the Seconda sonata the motif which owes something to the works of 1975-77 takes many forms, but it is immediately recognisable in most cases, with the intervals constantly changing, a hallmark of the composer's style and a strong unifying factor.

The freedom with which he treats the changing identity of his motifs gives a clue to the understanding of the variation technique in the Streichsextett über ein Thema von Frank Martin of 1990. Krek's choice of a theme by Frank Martin was a tribute to the nationality of the Swiss players, but it was also because of the affinity that Krek's music has with that of the Swiss composer. The work's emotional tone is very strong, with a powerful intensity immediately obvious in the harmonies found in the theme taken from the opening of the second movement of Frank Martin's Cello Concerto. This atmosphere is maintained throughout despite the many tempo changes and the constantly changing textures which are enabled by the six string parts. Although written as a continuous piece of nearly twenty minutes' duration, it is composed in nine distinct sections in a symmetrical pattern that owes little to traditional formal planning.

An all-important three-note motif appears immediately in all the string parts of Frank Martin's theme. This is taken in its original form and rescored for the string sextet, onto which Krek has spliced his music seamlessly. The variations, interludes and postlude that follow saturate the textures with these motifs and their imaginative transformations. The most important point is that the musical processes that Krek uses in the Streichsextett depend for their effect on an audible association of ideas. The fact that this constant flux of motifs is being handled so apparently effortlessly makes the work's intense expression easily communicated. It is in fact this combination of motivic economy and expressive sound that gives Krek's music its distinctive character and its unique power.

Krek's contribution to Slovene music has been considerable. His opus, although not prolific, has been consistent, emotionally strong and has employed the highest quality of musical craftsmanship. On the other hand it has shown a flexibility and variety that might not be expected from a composer who has not courted avant-garde trends, but has maintained a focus on traditional methods and styles. His music is never predictable, but the surprises are always measured and understated. Krek's music has a strong intellectual focus balanced by an instinctive dramatic sense, with the outstanding works, especially Inventiones ferales, Sinfonia per archi, the Sonata for clarinet and piano and 
the Streichsextett über ein Thema von Frank Martin, standing high in the European music of the 20th century.

POVZETEK

Glasba Uroša Kreka, ki je obče priznana zavoljo svoje kakovosti, se je le polagoma razvijala, in to brez modnih ali nenadnih sprememb stila. Nova dela organsko rastejo iz predhodnih, čeprav je njegov opus možno na splošno razdeliti na štiri obdobja, v katerih prevladujejo neoklasicistične ideje, vpliv ljudske glasbe, široka uporaba melodičnih celic ter kombinacij vseh omenjenih značilnosti. Neoklasicistična stilnost predstavlja osnovo njegovega glasbenega jezika v takšnih delih, kot je Simfonietta, medtem ko je obdobje Krekovega delovanja v Glasbenonarodopisnem inštitutu v Ljubljani dodatno zaznamovalo njegovo glasbeno govorico z uporabo ljudsko pogojenih melodij in ritmov. $\mathrm{V}$ zgodnjih sedemdesetih letih je Krek razvil svoj način uporabe melodičnih celic v vrsti komornih del, ki skupaj s Sinfonio per archi kažejo intelektualno plat njegovega glasbenega značaja. Istočasno se je Krek popolnoma oddaljil od tradicionalnih form. Od približno leta 1980 dalje je te različne tehnike začel povezovati na raznovrstne načine, tako da sta se poudarek kot tudi delovanje tehničnih procesov od skladbe do skladbe spreminjala. Ta čas je zaznamoval tudi nastanek precejšnjega števila vokalnih del. 